\title{
УКРАЇНСЬКА ТЕРМІНОЛОГІЯ НАФТОГАЗОВОЇ ПРОМИСЛОВОСТІ
}

\author{
СВІТЛАНА ДОРОШЕНКО \\ Полтавський національний технічний університет імені Юрія Кондратюка, \\ Полтава - Україна \\ UKRAIŃSKA TERMINOLOGIA \\ PRZEMYSŁU NAFTOWEGO I GAZOWEGO
}

SWITLANA DOROSZENKO

Połtawski Narodowy Uniwersytet Techniczny im. Jurija Kondratiuka, Połtawa - Ukraina

STRESZCZENIE. Artykuł poświęcony jest badaniu głównych etapów kształtowania ukraińskiej terminologii przemysłu naftowego i gazowego, wpływowi na nie czynników językowych i pozajęzykowych. W pracy przeanalizowano przyczyny i cechy synonimii i wariantywności w ukraińskiej terminologii przemysłu naftowego i gazowego, określono sposoby i metody tworzenia terminów.

\section{UKRAINIAN OIL AND GAS INDUSTRY TERMINOLOGY}

\section{SVITLANA DOROSHENKO}

Yuri Kondratyuk Poltava National Technical University, Poltava - Ukraine

ABSTRACT. The main stages of formation of Ukrainian oil and gas industry terminology are described in the article. The influence of linguistic and extra linguistic factors on the development of Ukrainian oil and gas industry terminology is investigated according to the origin. The reasons and peculiarities of synonymy and variance in Ukrainian oil and gas industry terminology have been analyzed. The ways and methods of term formation have been determined.

$\Phi$ ормування та розвиток української термінології нафтогазової промисловості тісно пов'язані з історією розвитку й становлення нафтогазової галузі та науки про неї й української літературної мови загалом.

Умовно можна виділити кілька етапів у розвитку аналізованої термінології, що збігаються з етапами становлення української науково-технічної термінології, оскільки досліджувана термінологія є іiї органічним складником. Упродовж століть функціонувала виробнича термінологія народних промислів, у якій виокремлювалася й термінологія нафтогазодобування.

В Україні про наявність нафти в ії надрах було відомо давно, свідченням чого є нафтопрояви, що були виявлені в копаних колодязях та грязьових вулканах на Керченському півострові ще в III ст. до н. е. Торговельні шляхи, що проходили через Крим, сприяли поширенню керченської нафти в містах Київської Русі. Як зазначає В. Німчук, „уже лексикон “Толкование неудобь познаваемомъ ... płчем" (список XIV ст.) містить термін навта з перекладом “см'шеніє алои и смола и воскъ съмєрдащимъ камєнїємъ”, запозичений із грецької мови, в яку 
ввійшов 3 іранської. Староукраїнський звуковий варіант нефта позначений тюркським впливом"1. 3 арабської nafth, nift від nafatha - кunimu, цю ж ознаку клекотіння, бурління, що супроводжувало вихід нафти на поверхню земної кори, ймовірно, було покладено в основу і праслов'янської назви кип 'ячка. Крім того, для позначення маслянистої горючої рідини, що використовувалася переважно в західній частині території сучасної України, вживали лексему ропа, запозичену з польської мови зі значенням “гірська смола".

Термін газ є штучним утворенням бельгійського хіміка I. ван Гельмінта (1577-1644) на основі латинського chaos або німецького gächen - кипimu. Можна припустити, що до того часу, як цей термін потрапив у праслов'янську мову, на території сучасної України газ, як і нафту, називали кип 'ячкою.

Отже, перший етап розвитку української термінології нафтогазової промисловості — 3 XIII ст. і до кінця XIX ст. — це зародження зазначеної терміносистеми.

Українська нафтогазова наука почала формуватися в кінці XIX ст. Це й стало початком другого етапу розвитку термінології цієї галузі. 3 того часу термінологію почали творити свідомо, оскільки в ній мали гостру потребу фахівці та науковці.

Наступний етап розвитку термінології нафтогазової справи припадає на 20-ті роки XX ст. і пов'язаний він із діяльністю Інституту української наукової мови. Цей час характеризується бурхливим розвитком термінотворення, адже тогочасні суспільно-політичні умови сприяли формуванню самостійної потужної мови української науки й техніки.

Однак уже 3 30-х років XX ст. почалася репресія що стосувалася й тих, хто творив національну термінологію, наслідки якої відбилися й на сучасному стані української науково-технічної мови. Період застою в розвитку української термінології тривав аж до 90-х років ХХ ст.

Після здобуття незалежності в Україні нафтогазова галузь стала однією 3 найпрогресивніших галузей промисловості, тому стимулом розвитку термінології на нинішньому етапі є досягнення сучасної науки та техніки. Крім того, постійно зростає інтерес до проблем термінології як з боку галузевих фахівців, так і з боку лінгвістів. На сьогодні вивчаються теоретичні проблеми термінології, формування й становлення термінологій окремих галузей і розв'язуються практичні завдання щодо внормування та стандартизації української науково-технічної термінолексики.

Словниковий склад української мови - це відкрита, динамічна система лексичних одиниць, різнопланових за джерелами й часом формування $^{2}$. Термінологія як підсистема лексичної системи української мови також неоднорідна щодо походження.

„Практично ні одна природна мова при творенні термінів не може обійтися своїми власними ресурсами, тому термінологія багатьох галузей знань різних мов послуговується лексичними та словотворчими засобами високорозвинутих літературних мов"3. Отже, з огляду на генетику терміни нафтогазової промисловості поділяються на власномовні, запозичені та такі, що складаються 3 національних та іншомовних елементів.

\footnotetext{
${ }^{1}$ В. В. Німчук, Давньоруська спадщзина в лексиці украӥнської мови, Київ 1992, с. 141.

${ }^{2}$ А. П. Грищенко, Л. І. Мацько, М. Я. Плющ та ін., Сучасна украӥнська літерамурна мова, Київ 1997, с. 174.

3 Л. О. С и м он ен ко, Українська термінологія кіния XX сm., [в:] Українська термінологія i сучасність, Матер. II Всеукр. наук. конф., Київ 1997, с. 10.
} 
Власномовні терміни становлять основу всіх національних термінологій. До складу термінології нафтогазової промисловості входять передусім національні терміни праслов'янського походження: вода, зерно, земля, потік, робота, поле, щзит, надра, віск; смола, пісок, подушка; давньоруського походження: труба, поріг, договір, шолом, порошок тощо і власне українські: тріщчна, тиск, двигун, з'єднання, пружність, прояв, прошарок, потреба, напусток, напрямок, буріння, свердловина, рух, розчин, промивання, порода, поклад, пласт, вологість, обладнання, обертач, повітря, камінь, родовище. Загальномовні слова, входячи в термінологічне словосполучення, можуть набувати іншого значення, напр.: повітряна подушка — „пневматичний пристрій, що використовується для маневрування великими важкокерованими конструкціями, зокрема такими, як круглі резервуари - сховища" ${ }^{4}$ i т. ін.

Серед запозичень виділяють міжнародні терміни, що функціонують із тим самим значенням не менше ніж у трьох неблизькоспоріднених мовах 5 . У досліджуваній термінології спостерігаємо велику кількість таких запозичень, напр.: помпа - англ. рump, франц. ротре, італ. ротра, ісп. ротра, польс. ротра; газ — poc. газ, англ. gas, франц. gaz та ін.

У досліджувану термінологію запозичення потрапляли в різні періоди і з різною інтенсивністю. Особливо активно відбувалося проникнення запозичень в українську термінологію нафтогазової промисловості в другій половині XIX ст. Це пов' язане насамперед із зародженням нафтогазової науки й тим, що саме в цей час мовознавці почали писати свої дослідження українською мовою. Крім того, відбувалися контакти з європейськими науковцями, що й спричинило запозичення в національну термінологію готових мовних одиниць разом із поняттями й реаліями, назвами яких вони є.

Найбільшу частину термінів іншомовного походження в складі досліджуваної термінології становлять запозичення з класичних мов - латинської та грецької. Латинській мові належала особлива роль у середньовічній Свропі, оскільки вона практично безроздільно панувала в науці, освіті, юриспруденції й інших сферах життя. Ще 3 того часу латинізми стали джерелом поповнення наукових термінологій усіх європейських мов. Оскільки ж класична латина була переповнена грецькими запозиченнями, то грецька мова теж стала лексичним резервом для побудови нових термінів. Учені зауважують, що „саме терміноелементи грецько-латинського походження і є справжніми інтернаціоналізмами, бо вони не належать до жодних із живих мов, тому вони є однаково чужими та одночасно рідними для будь-якої мови"б. Запозичення, що функціонують у досліджуваній термінології, належать як до давніх, так і до пізніших.

Iз XVII ст. 3'являється багато понять, не відомих античній і середньовічній науці, тому греко-латинське джерело запозичень майже вичерпалося, вплив латини послабився. Починається другий етап запозичень, основними з яких були французькі, німецькі та англійські.

До складу термінології нафтогазової промисловості входить чимало так званих гібридних утворень, тобто слів, утворених одночасно з національної та інтернаціональної морфем ${ }^{7}$. Дослідники вказують, що „серед термінів $з$ про-

${ }^{4}$ В. С. Білецький, К. Ф. Сапіцький, Б. С. Панов та ін., Тлумачний гірничий словник, Донецьк 1998, с. 446.

${ }^{5}$ T. І. Панько, І. М. Кочан, Вироблення украӥнських термінологічних стандартів, [в:] „Вісник АН України” 1991, № 12, с. 18.

${ }^{6}$ А. С. Д'яков, Т. Р. Кия к, З. Б. Куделько, Основи термінотворення. Семантичні та соиіолінгвістичні аспекти, Київ 2000, с. 113.

7 Л. О. Симоненко, С. О. Соколова, І. В. Кононенко та ін., Національні та інтернаціональні компоненти в сучасних терміносистемах, Київ 1993, с. 177. 
стою основою переважають гібриди, в яких корінь - іншомовна за походженням морфема, а афікси є національними або гібридними"в. В аналізованій терміносистемі це такі терміни, як гідрування, коксування, протикорозійний (захист), розпакерування, розгерметизація тощо.

Термінологія нафтогазової промисловості, як і інші галузеві терміносистеми, є польовою структурою з чітко вираженим ядром, яке формують терміни, безпосередньо пов'язані з процесами видобування нафти й газу, а на периферії містяться міжгалузеві терміни. У складі досліджуваної термінології виділяються 12 лексико-тематичних груп, що є свідченням їі значної розгалуженості.

Синонімія в термінології нафтогазової промисловості є об'єктивно існуючим мовним явищем, хоч і заперечується деякими дослідниками. Серед причин виникнення синонімів у термінології однією з найважливіших $є$ паралельне вживання автохтонного й іншомовного термінів на позначення одного й того ж поняття, що породжує термінологічну дублетність. Крім абсолютних синонімів, у складі аналізованої термінології виявлена невелика кількість відносних синонімів, у яких, окрім спільних сем, є ще й відмінні. Зі структурного боку до складу синонімічного термінологічного об'єднання можуть входити слова, словосполучення та абревіатури.

Близькою до проблеми синонімії $є$ проблема варіантності в термінології. Хоча серед науковців існує думка, що чітко окреслене поняття науки й техніки має бути співвіднесене з однією одиницею плану вираження, варіантність термінів — це об'єктивно наявне мовне явище. У процесі вивчення термінологічної варіантності виникає питання, пов'язане з класифікацією термінів-варіантів. Спираючись на класифікації термінів-варіантів за формальною ознакою (поділ варіантних одиниць залежно від того формального елемента, що відрізняє один варіант від іншого), подані О. Радченко ${ }^{9}$ та М. Карп’юк ${ }^{10}$, серед варіантів термінології нафтогазової промисловості пропонується виділити такі групи:

1. Фонематичні варіанти. Фонематична варіантність установлюється в модифікаціях терміна, які різняться фонемами, що не виконують смислорозрізнювальної функції, тобто втратили фонологічне протиставлення, але зберігають при цьому свої фізіолого-акустичні ознаки ${ }^{11}$. Фонематичні варіанти досить чисельні й різноманітні. Серед них назвемо основні підгрупи: 1) фонематична варіантність у префіксах термінологічних одиниць: упорядкування - впорядкування; 2) фонематична варіантність у коренях термінів: а) приголосні фонеми: нержавіючий - неіржавіючий; б) голосні фонеми: фланцева - флянцева (заглушка), загоряння - загорання (вибухових речовин), флюоресценція флуоресценція; 3) фонетична варіантність у суфіксах термінів: глиниста - глиняста (порода).

2. Акцентні варіанти. Такі варіювання виникають унаслідок нейтралізації наголосу як щодо значення термінів, так і стосовно розрізнення їх форм (водопрові́дний-водопровідний).

3. Граматичні варіанти. Вони також пов'язані зі зміною звукової оболонки терміна, що в цьому разі впливає на його граматичне значення. Отож,

${ }^{8}$ Там само, с. 178.

9 О. Р адч ен ко, Про терміни-варіанти, [в:] „Вісник: Проблеми української термінології” 1998, № 336, с. 70-71.

${ }^{10}$ М. Д. Карп 'юк, До питання про класифікацію варіантів слова, [в:] „Мовознавство”, 1979, № 3, с. 60 .

${ }^{11} \mathrm{O}$. Р а дч ен ко, зазн. джерело, с. 70. 
варіювання в закінченнях термінологічних одиниць на зразок „нуль звука - голосна фонема", що змінює форму роду терміна, тип його відмінювання тощо, вважаємо граматичним варіюванням (аналіз - аналіза, манжет - манжета, автокар - автокара, иерезин - церезина).

4. Словотвірні варіанти. Стосовно визначення цього поняття постає питання, чи вважати терміни, що утворені від одного кореня за допомогою різних афіксів, які мають однакове лексичне та граматичне значення, словотвірними синонімами або словотвірними варіантами. О. Ахманова й деякі інші вчені, напр., стверджують, що між спільнокореневими утвореннями з тим самим значенням не може бути зв'язків синонімічного характеру ${ }^{12}$, тоді як I. Ковалик ряди однозначних утворень 3 однаковою словотвірною основою, $з$ однозначними, але різнозвучними афіксами відносить до словотвірних афіксальних синонімів ${ }^{13}$.

Погоджуючись із думкою, що такі терміни є словотвірними варіантами, виділяємо найтиповіші словотвірні варіювання в термінології нафтогазової промисловості: а) суфіксальні: обертовий - обертальний (превентор), промивний - промивальний (клапан), газозбірник - газозбирач, труборозиирник труборозщирювач; б) префіксальні: зневоднення - обезводнення (нафти), неперервний - безперервний (газліфт), протикорозійне - антикорозійне (покриття).

Варіювання можливе на рівні однієї словотвірної моделі: загострення загострювання, окиснення - окиснювання, приростання - прирощування. У цьому разі маємо, очевидно, відносну варіантність, під якою Е. Головіна розуміє „часткову тотожність матеріального оформлення при тотожності значень, а також при частковій розбіжності в плані змісту"14, оскільки такі пари диференціюють характеристику позначуваного ними процесу щодо тривалості.

5. Синтаксичні варіанти. Такі види варіантів пов'язані з різними можливими видами зв'язку в термінологічних словосполученнях: (кріплення свердловин - свердловинне кріплення; буріння на глибині - глибинне буріння).

Подана класифікація відображає сучасний стан розвитку української термінології нафтогазової промисловості. Як уже зазначалося, наявність варіантів свідчить про недостатньо високий рівень упорядкованості досліджуваної термінології. В останні роки існує виразна тенденція до зменшення кількості термінів-варіантів, особливо фонетичних, що $є$ наслідком плідної діяльності українських термінологів у сфері стандартизації та внормування галузевих термінологій.

Упорядкування й систематизація української термінології нафтогазової промисловості тісно пов'язані з виявленням арсеналу словотвірних засобів, що використовуються для творення термінів, 3 установленням генетичних зв’ язків термінів з іншими словами та загальних закономірностей деривації цієї підгрупи лексики.

Мовознавці вважають термінологічне словотворення цілком свідомим процесом. Г. Винокур писав: „Терміни не „виникають”, а „придумуються”, „творяться" в міру усвідомлення їхньої необхідності" 15 . У час творення деяких термінів відомі їхні автори, напр., термін озокерит (“земний віск”) створив

${ }^{12}$ O. С. Ахман в в а, Словарь лингвистических терминов, Москва 1966, с. 232.

${ }^{13}$ I. I. Ковалик, Вчення про словотвір, Львів 1961, с. 83.

14 Э. Д. Голов ина, К типологии языковой вариантности, [в:] „Вопросы языкознания”, 1983, № 2, c. 61 .

${ }^{15}$ Г. О. В и н о ку р, О некоторых явлениях словообразования в русской технической терминологии, [в:] „Труды МИИФЛИ” Москва 1939, т. 5, с. 46. 
1833 р. Е. Локер, термін парафін (“воскоподібна легкоплавка речовина”) німецький хімік К. Райхенбах (1788-1869) ${ }^{16}$.

Акт термінологічного словотворення знаходиться в тісній залежності від класифікації понять. У низці цих понять буде міститися термін, що створюється як найменування даної низки, оскільки терміни одного класифікаційного ряду по можливості мають бути утворені за однією словотвірною моделлю ${ }^{17}$.

Основні закони деривації і функціонування термінологічної лексики такі самі, як і відповідні закони лексики загальновживаної. Проте творення термінології нафтогазової промисловості має свої особливості, що виявляються в продуктивності способів, засобів та моделей термінотворення.

В. Даниленко виділяє три основні способи творення термінів: 1) семантичний, що полягає в переосмисленні слів, узятих із загальновживаної мови; 2) морфологічний, що включає процеси деривації і словоскладання; 3) синтаксичний, що репрезентує словотворення термінологічних словосполучень.

Лексико-семантичний спосіб словотворення $є$ засобом поповнення української термінології нафтогазової промисловості протягом усього іiі розвитку. Процес вторинної номінації в термінології нафтогазової промисловості здійснюється трьома способами: звуженням значення загальновживаного слова, метафоричним перенесенням та метонімічним перенесенням значення.

Одним із основних способів деривації для термінів нафтогазової промисловості є морфологічний, що зумовлено насамперед тим, що цей спосіб найбільш поширений і для слів загальновживаної мови. Найбільш продуктивна в аналізованій термінології афіксація, що представлена суфіксальним, префіксальним та префіксально-суфіксальним різновидами. За допомогою суфіксації твориться більшість термінів, причому використовуються як суфікси, властиві словам загальновживаної мови (-нн-, -ач, -ор, -к-, -ок), так і власне термінологічні (-ат, -ит (-іт), -ол). Префіксація найбільш характерна для творення термінів, що застосовуються для найменувань деталей, механізмів і т. ін. Використовуються власномовні префікси (під-, напів-, над-, суб, не-) і запозичені (а-, анти-, дез-, де-, ре-). Префіксально-суфіксальним способом творяться терміни-дієслова для позначення технічних і виробничих дій у нафтогазовій термінології. Найчастіше такі дієслова утворюються від іменникової основи за допомогою суфіксів -и-, -і-, -ува- та префіксів ви-, в-, за-, з-, по-, про-, пере-, під-, на-,с-, о-, об-, від-, у-, при-.

Активним способом термінотворення виявився синтаксичний, що репрезентує творення термінологічних словосполучень. Це зумовлено тим, що терміносполучення володіє низкою мовних та позамовних переваг порівняно iз терміном-словом (здатністю виражати складні поняття, системні поняттєві зв’язки тощо). У структурі складного найменування головне слово передає родову ознаку (категоріальне значення), а залежне — видову (конкретні індивідуальні особливості речей, явищ, процесів, механізмів тощо). Найбільш поширеними є такі моделі: “прикметник + іменник”, “іменник + іменник”, “прикметник (дієприкметник) + іменник + іменник”, “іменник + іменник + іменник”, “ прикметник + іменник +іменник + іменник” та ін.

На сучасному етапі розвитку української терміносистеми нафтогазової справи основною є проблема унормування та стандартизації, що передбачає впорядкування системи понять цієї галузі і термінів на їх позначення.

${ }^{16}$ Етимологічний словник украӥнської мови в 7 m., редкол.: О. С. Мельничук та ін., Київ 2003, т. 4, c. 167.

${ }^{17}$ В. П. Дан иле н ко, Русская терминология: Опьт лингвистического описания, Москва 1977, c. 91. 
Унормування термінології нафтогазової промисловості шляхом усунення синонімії, варіантності, вилучення непродуктивних словотвірних типів сприятиме поліпшенню системної організації аналізованої терміносистеми.

Загалом синхронно-діахронний аналіз української термінології нафтогазової промисловості підтверджує думку, що досліджувана термінологія є відкритою системою, що постійно розвивається й розширює свій функціональний статус. Особливості системної організації термінів на семантичному й структурному рівнях зумовлюють потребу виділення термінології нафтогазової промисловості в окрему підсистему загальнолітературної мови. 